\title{
7 \\ The Fourth Prerequisite: Support Prison Staff to Treat Imprisoned People in a Human Rights-Consistent Manner
}

\section{Introduction}

Prison staff have daily interactions with imprisoned people and international human rights law seeks to regulate these interactions in two important ways. The first is by requiring that imprisoned people are not 'subjected to torture or to cruel, inhuman or degrading treatment or punishment' (TCID). ${ }^{1}$ This will be referred to as the prohibition against TCID. The second is by requiring that '[a]ll persons deprived of their

\footnotetext{
1 Convention against Torture and Other Cruel, Inhuman or Degrading Treatment or Punishment, opened for signature 10 December 1984, 1465 UNTS 85 (entered into force 26 June 1987) ('CAT'); International Covenant on Civil and Political Rights, opened for signature 19 December 1966, 999 UNTS 171 (entered into force 23 March 1976) art 7 ('ICCPR'); Convention on the Rights of Persons with Disabilities, opened for signature 30 March 2007, 2515 UNTS 3 (entered into force 3 May 2008) art 15 ('CRPD'). This requirement has been incorporated directly into Victorian, Australian Capital Territory (ACT) and Queensland law by s 10 of the Charter of Human Rights and Responsibilities Act 2006 (Vic) s 10 ('Charter'), Human Rights Act 2004 (ACT) s 10 ('HRA') and Human Rights Act 2019 (Qld) s 17, respectively. See also Corrections Management Act 2007 (ACT) s 9(c) ('CMA') (discussed in more detail in Chapter 5).
} 
liberty shall be treated with humanity and with respect for the inherent dignity of the human person'. ${ }^{2}$ This will be referred to as the requirement that people be treated with humanity and respect.

These obligations may be described as two sides of the same coin, with one requirement being positive and the other negative. One way of precluding TCID is to ensure that people are treated with humanity and respect. If that happens, there is little likelihood of TCID. The prevention of TCID will be the focus of the international and domestic monitoring bodies that inspect prisons now that Australia has ratified the Optional Protocol to the Convention against Torture and Other Cruel, Inhuman or Degrading Treatment or Punishment (OPCAT). ${ }^{3}$ This adds a level of urgency to compliance with this prerequisite.

From the perspective of imprisoned people, this is a prerequisite that can make a major difference in their experience of imprisonment. In qualitative research about people's experiences of imprisonment, people will commonly refer to the absence of respectful treatment as one of the most challenging aspects of their incarceration, and this may cause distress, anxiety and depression. ${ }^{4}$ Extensive empirical research conducted in prisons in the United Kingdom (UK) has led Liebling to characterise the importance of respect as follows: ' $[t]$ he absence of respect and fairness is experienced as psychologically painful. Being treated disrespectfully or without dignity generates negative emotions such as anger, tension, indignation, depression and rage. ${ }^{5}$

It is recognised at the outset that there are several challenges to achieving these obligations in practice. These include the fact that they are abstract and require further explanation about the types of practices and behaviour that are consistent with, or run counter to, compliance with them. There is also the fact that prisons are coercive and hierarchical environments'total institutions' as outlined in Chapter 1. It was noted in Chapter 4 that 'detention conditions ... in some circumstances can also be a means

2 ICCPR art 10(1). This requirement has been incorporated into Victorian, ACT and Queensland law by the Charter s 22, HRA s 19 and Human Rights Act 2019 (Qld) s 30, respectively. See also CMA ss7(c), 9(a) (discussed in more detail in Chapter 5).

3 Optional Protocol to the Convention against Torture, adopted 18 December 1992, UN Doc A/RES/ 57/199 (entered into force 22 June 2006) ('OPCAT').

4 Bronwyn Naylor, 'Human Rights and Respect in Prisons: The Prisoners' Perspective' in Bronwyn Naylor, Julie Debeljak and Anita Mackay (eds), Human Rights in Closed Environments (Federation Press, 2014); Alison Liebling, 'Moral Performance, Inhuman and Degrading Treatment and Prison Pain' (2011) 13(5) Punishment \& Society 530; Karin Beijersbergen et al, 'Procedural Justice and Prisoners' Mental Health Problems: A Longitudinal Study' (2014) 24 Criminal Behaviour and Mental Health 100, 101.

5 Liebling, above $\mathrm{n} 4,534$. 
of torture'. ${ }^{6}$ That is, simply being in a prison may constitute TCID. The hierarchical environment also means that there is always going to be a power imbalance between staff and imprisoned people, and it can be difficult to get those in power to behave in a respectful manner towards those in their custody.

\section{International Guidance on the International Law Requirements and Their Interpretation}

There are three main sources of international law: treaties, 'soft' law, and General Comments issued by treaty monitoring bodies (TMBs). The treaty requirements were detailed in Chapter 2, so the next section in this chapter will consider the remaining international law requirements. The TMBs' views expressed in response to individual communications are important for understanding how the treaty obligations are to be interpreted and will be considered in the following section.

\section{Rules, Principles and General Comments}

This section aims to draw out as much detail as possible from soft law and TMBs to clarify the prohibition against TCID and the requirement that people be treated with humanity and respect.

The three most relevant 'soft' law requirements relating to imprisonment are the United Nations (UN) Standard Minimum Rules for the Treatment of Prisoners (the Nelson Mandela Rules) ('the Mandela Rules'), UN Rules for the Treatment of Women Prisoners and Non-Custodial Measures for Women Offenders ('the Bangkok Rules') and UN Body of Principles for the Protection of All Persons under Any Form of Detention or Imprisonment ('Body of Principles'). ${ }^{8}$ Some examples of these were provided in Chapter 2.

6 Subcommittee for the Prevention of Torture and Other Cruel, Inhuman or Degrading Treatment or Punishment, The Approach of the Subcommittee on Prevention of Torture to the Concept of Prevention of Torture and Other Cruel, Inhuman or Degrading Treatment or Punishment Under the Optional Protocol to the Convention Against Torture and Other Cruel, Inhuman or Degrading Treatment or Punishment, CAT/OP/12/6 (30 December 2010) 5(d).

7 Crewe notes 'there are always difficulties in sustaining positive staff-prisoner relationships in an environment that is ultimately coercive': Ben Crewe, 'Soft Power in Prison: Implications for StaffPrisoner Relationships, Liberty and Legitimacy' (2011) 8(6) European Journal of Criminology 455, 463. 8 United Nations Standard Minimum Rules for the Treatment of Prisoners (the Nelson Mandela Rules), UN Doc A/RES/70/175 (17 December 2015) ('the Mandela Rules'); United Nations Rules for the Treatment of Women Prisoners and Non-Custodial Measures for Women Offenders, UN Doc A/RES/ 65/229 (adopted by the General Assembly on 21 December 2010) ('the Bangkok Rules'). 
Extracts of some of the relevant rules, categorised according to the two treaty obligations, are provided in Tables 7.1 (Rules relating to the prohibition of TCID), 7.2 (the Mandela Rules relating to treatment with humanity and respect) and 7.3 (the Bangkok Rules relating to treatment with humanity and respect). There is also an additional rule that does not relate to either treaty obligation, but is relevant to the appropriateness of the prison setting for some people. This is Mandela Rule 109, which provides that:

persons who are found to be not criminally responsible, or who are later diagnosed with severe mental disabilities and/or health conditions, for whom staying in prison would mean an exacerbation of their condition, shall not be detained in prisons, and arrangements shall be made to transfer them to mental health facilities as soon as possible.

A separate table (Table 7.4) is provided for the Body of Principles because most of these relate to the prohibition against TCID (only Principle 1 is relevant to treatment with humanity and respect).

Table 7.1: The Mandela Rules Relating to the Prohibition of 'Torture and Other Cruel, Inhuman or Degrading Treatment or Punishment'

\begin{tabular}{|c|c|}
\hline The Mandela Rules & The Bangkok Rules \\
\hline $\begin{array}{l}\text { Rule } 44 \text { (Solitary confinement) } \\
\text { For the purpose of these rules, solitary confinement } \\
\text { shall refer to the confinement of prisoners for } \\
22 \text { hours or more a day without meaningful human } \\
\text { contact. Prolonged solitary confinement shall refer } \\
\text { to solitary confinement for a time period in excess of } \\
15 \text { consecutive days. } \\
\text { Rule } 45 \text { (Solitary confinement) } \\
\text { 1. Solitary confinement shall be used only in } \\
\text { exceptional cases as a last resort, for as short } \\
\text { a time as possible and subject to independent } \\
\text { review, and only pursuant to the authorization by } \\
\text { a competent authority. It shall not be imposed by } \\
\text { virtue of a prisoner's sentence. } \\
\text { 2. The imposition of solitary confinement should be } \\
\text { prohibited in the case of prisoners with mental } \\
\text { or physical disabilities when their conditions } \\
\text { would be exacerbated by such measures. The } \\
\text { prohibition of the use of solitary confinement and } \\
\text { similar measures in cases involving women and } \\
\text { children, as referred to in other United Nations } \\
\text { standards and norms in crime prevention and } \\
\text { criminal justice, continues to apply. }\end{array}$ & $\begin{array}{l}\text { Rule } 22 \text { (Confinement) } \\
\text { Punishment by close confinement } \\
\text { or disciplinary segregation shall } \\
\text { not be applied to pregnant } \\
\text { women, women with infants and } \\
\text { breastfeeding mothers in prison. }\end{array}$ \\
\hline
\end{tabular}




\section{The Mandela Rules}

Rule 47 (Use of restraint)

1. The use of chains, irons or other instruments of restraint which are inherently degrading or painful shall be prohibited.

2. Other instruments of restraint shall only be used when authorized by law and in the following circumstances:

(a) As a precaution against escape during a transfer, provided that they are removed when the prisoner appears before a judicial or administrative authority;

(b) By order of the prison director, if other methods of control fail, in order to prevent a prisoner from injuring himself or herself or others or from damaging property; in such instances, the director shall immediately alert the physician or other qualified health-care professionals and report to the higher administrative authority.

\section{The Bangkok Rules}

Rule 24 (Restraint)

Instruments of restraint shall never be used on women during labour, during birth and immediately after birth.

\section{Table 7.2: The Mandela Rules Relating to Treatment with Humanity and Respect}

\section{Rule 5(1) (Normality)}

The prison regime should seek to minimize any differences between prison life and life at liberty that tend to lessen the responsibility of the prisoners or the respect due to their dignity as human beings.

\section{Rule 50 (Searches)}

The laws and regulations governing searches of prisoners and cells shall be in accordance with obligations under international law and shall take into account international standards and norms, keeping in mind the need to ensure security in the prison. Searches shall be conducted in a manner that is respectful of the inherent human dignity and privacy of the individual being searched, as well as the principles of proportionality, legality and necessity.

\section{Rule 74 (Staff recruitment)}

The prison administration shall provide for the careful selection of every grade of the personnel, since it is on their integrity, humanity, professional capacity and personal suitability for the work that the proper administration of prisons depends.

\section{Table 7.3: The Bangkok Rules Relating to Treatment with Humanity and Respect}

\section{Rule 5 (Personal hygiene)}

The accommodation of women prisoners shall have facilities and materials required to meet women's specific hygiene needs, including sanitary towels provided free of charge and a regular supply of water to be made available for the personal care of children and women, in particular women involved in cooking and those who are pregnant, breastfeeding or menstruating.

\section{Rule 8 (Medical privacy)}

The right of women prisoners to medical confidentiality, including specifically the right not to share information and not to undergo screening in relation to their reproductive health history, shall be respected at all times. 


\section{Rule 10 (Gender-specific health care)}

1. Gender-specific health-care services at least equivalent to those available in the community shall be provided to women prisoners.

2. If a woman prisoner requests that she be examined or treated by a woman physician or nurse, a woman physician or nurse shall be made available to the extent possible, except for situations requiring urgent medical intervention. If a male medical practitioner undertakes the examination contrary to the wishes of the woman prisoner, a woman staff member shall be present during the examination.

\section{Rule 11 (Gender-specific health care)}

1. Only medical staff shall be present during medical examinations unless the doctor is of the view that exceptional circumstances exist or the doctor requests a member of the prison staff to be present for security reasons or the woman prisoner specifically requests the presence of a member of staff as indicated in rule 10, paragraph 2 above.

2. If it is necessary for non-medical prison staff to be present during medical examinations, such staff should be women and examinations shall be carried out in a manner that safeguards privacy, dignity and confidentiality.

\section{Table 7.4: Body of Principles}

\section{Principle 1}

All persons under any form of detention or imprisonment shall be treated in a humane manner and with respect for the inherent dignity of the human person.

\section{Principle 6}

No person under any form of detention or imprisonment shall be subjected to torture or to cruel, inhuman or degrading treatment or punishment. ${ }^{*}$ No circumstance whatever may be invoked as a justification for torture or other cruel, inhuman or degrading treatment or punishment.

* The term 'cruel, inhuman or degrading treatment or punishment' should be interpreted so as to extend the widest possible protection against abuses, whether physical or mental, including the holding of a detained or imprisoned person in conditions which deprive him [sic], temporarily or permanently, of the use of any of his [sic] natural senses, such as sight or hearing, or of his [sic] awareness of place and the passing of time.

\section{Principle 21}

1. It shall be prohibited to take undue advantage of the situation of a detained or imprisoned person for the purpose of compelling him [sic] to confess, to incriminate himself [sic] otherwise or to testify against any other person.

2. No detained person while being interrogated shall be subject to violence, threats or methods of interrogation which impair his [sic] capacity of decision or his [sic] judgement.

\section{Principle 22}

No detained or imprisoned person shall, even with his [sic] consent, be subjected to any medical or scientific experimentation which may be detrimental to his [sic] health.

\section{Principle 33}

1. A detained or imprisoned person or his [sic] counsel shall have the right to make a request or complaint regarding his [sic] treatment, in particular in case of torture or other cruel, inhuman or degrading treatment, to the authorities responsible for the administration of the place of detention and to higher authorities and, when necessary, to appropriate authorities vested with reviewing or remedial powers. 
One of the most helpful pieces of guidance comes from General Comment 21 (GC 21), relating to art 10(1) of the International Covenant on Civil and Political Rights (ICCPR), issued by the Human Rights Committee (HR Committee) (the TMB responsible for interpreting the ICCPR). GC 21 outlines the interrelationship of the prohibition against TCID contained in art 7 of the ICCPR and the requirement that people be treated with humanity and respect contained in art 10(1) of the ICCPR. The HR Committee states:

Article 10, paragraph 1, imposes on States parties a positive obligation towards persons who are particularly vulnerable because of their status as persons deprived of liberty, and complements for them the ban on torture or other cruel, inhuman or degrading treatment or punishment contained in article 7 of the Covenant. Thus, not only may persons deprived of their liberty not be subjected to treatment that is contrary to article 7 , including medical or scientific experimentation, but neither may they be subjected to any hardship or constraint other than that resulting from the deprivation of liberty; respect for the dignity of such persons must be guaranteed under the same conditions as for that of free persons. ${ }^{9}$

GC 21 also clarifies that a lack of resources is not a justification for failing to treat people with humanity and respect. ${ }^{10}$ This reasoning precludes Australia from arguing that the growth of the prison population and failure of prison infrastructure and staffing to keep pace with this growth are an excuse for lack of compliance. ${ }^{11}$

General Comment 20 (GC 20) relates to art 7 of the ICCPR. This clarifies that TCID includes treatment that causes either physical pain or mental suffering. ${ }^{12}$ It notes that 'prolonged solitary confinement' may constitute TCID and that states parties must undertake a variety of measures to prevent TCID, including 'States parties should inform the Committee of the legislative, administrative, judicial and other measures they take to prevent and punish acts of torture and cruel, inhuman and degrading treatment in any territory under their jurisdiction. ${ }^{13}$

9 United Nations Human Rights Committee, CCPR General Comment No. 21: Article 10 (Humane Treatment of Persons Deprived of Their Liberty) (10 April 1992) [3].

10 'Treating all persons deprived of their liberty with humanity and with respect for their dignity is a fundamental and universally applicable rule. Consequently, the application of this rule, as a minimum, cannot be dependent on the material resources available in the State party': ibid [4].

11 This growth and concomitant pressure on infrastructure was detailed in Chapters 1 and 4.

12 United Nations Human Rights Committee, CCPR General Comment No. 20: Article 7 (Prohibition of Torture, or Other Cruel, Inhuman or Degrading Treatment or Punishment) (10 March 1992) [5].

13 Ibid [6], [8]. 


\section{Views of Treaty Monitoring Bodies}

The views of TMBs are instructive. There are some general points to be made before the views in some specific instances are outlined. The first is that the HR Committee has found situations that violate either art 7 or art 10(1) of the ICCPR, or both articles. Shah has helpfully explained that a violation of art 10(1) might occur when there are 'attacks on dignity that do not reach the severity of suffering threshold required by Article 7'. ${ }^{14}$

The second point to note is that in all instances the HR Committee will take a holistic view of the circumstances in the matter before them. The HR Committee looks at matters such as 'the nature and context of the treatment, its duration, its physical and mental effects and, in some instances, the sex, age, state of health or other status of the victim'. ${ }^{15}$ Even though there is a lower threshold for a violation of art 10(1) to occur compared to a violation of art 7 , there is still a 'minimum level of severity that must be reached'. ${ }^{16}$

The third point is that the obligations are non-derogable, which means that they cannot be suspended even in a 'time of public emergency'. ${ }^{17}$ Article 7 is specifically listed as a non-derogable Treaty provision in art 4(2) of the ICCPR, and the information about the non-derogability of art 10(1) comes from a General Comment from the HR Committee:

In those provisions of the Covenant that are not listed in article 4, paragraph 2, there are elements that in the Committee's opinion cannot be made subject to lawful derogation under article 4. Some illustrative examples are presented below.

(a) All persons deprived of their liberty shall be treated with humanity and with respect for the inherent dignity of the human person. Although this right, prescribed in article 10 of the Covenant, is not separately mentioned in the list of non-derogable rights in article 4, paragraph 2, the Committee believes that here the Covenant expresses a norm of general international law not

14 Sangeeta Shah, 'Detention and Trial' in Daniel Moeckli et al (eds), International Human Rights Law (Oxford University Press, 2014) 259.

15 Human Rights Committee, Views: Communication No 1184/2003, UN Doc CCPR/C/86/D/ 1184/2003 (17 March 2006) ('Brough v Australia') [9.2].

16 Anita Mackay, 'Article 10(1) of the International Covenant on Civil and Political Rights (ICCPR) and Australian Prisons' (2017) 23(3) Australian Journal of Human Rights 368, 370.

17 ICCPR art 4(1). 
subject to derogation. This is supported by the reference to the inherent dignity of the human person in the preamble to the Covenant and by the close connection between articles 7 and $10 .{ }^{18}$

The fact that art 10(1) is the first example provided by the HR Committee is indicative of the importance of this Article. It also reinforces the interrelationship between the two articles.

There are some communications considered by the HR Committee and other $\mathrm{TMB}$ that are especially relevant to the problematic practices in Australian prisons, that will be discussed later in this chapter (under 'Problematic Practices in Australian Prisons').

Solitary confinement has been a consistent theme in communications involving violations. The Committee against Torture (CAT/C) (the TMB responsible for interpreting the Convention against Torture and Other Cruel, Inhuman or Degrading Treatment or Punishment (CAT)) considered a particularly egregious case of solitary confinement relating to Tunisia in 2017. The complainant had been held in solitary confinement for a period of four years in one prison and a period of five months in another. For 30 months, he had one leg and one arm chained to the wall. He was also kept in a cell without windows and not allowed to leave the cell even to shower. ${ }^{19} \mathrm{He}$ was also subjected to repeated sessions where the 'guards beat his entire body with batons, plastic pipes and kicks' and other types of abuse. ${ }^{20}$ The CAT/C found that the complainant had been subjected to torture and was continuing to suffer 'severe physical and psychological after-effects'. ${ }^{21}$

The HR Committee has also found violations of art 7 of the ICCPR in a complaint involving solitary confinement in Uzbekistan. ${ }^{22}$ The complainant was held in solitary confinement for 112 days, in contravention of the local laws that prohibited solitary confinement for

18 United Nations Human Rights Committee, General Comment 29, States of Emergency (Article 4), UN Doc CCPR/C/21/Rev.1/Add.11 (2001) [13].

19 Committee against Torture, Views: Communication No 654/2015, UN Doc CAT/C/61/D/ 654/2015 (11 August 2017) ('Jaïdane v Tunisia') [2.11], [2/17].

20 Ibid [2.13].

21 Ibid [3.2], [3.5].

22 Human Rights Committee, Views: Communication No 2234/2013, UN Doc CCPR/C/114/D/ 2234/2013 (23 July 2015) ('M.T. v Uzbekistan') [7.1]-[7.4]. For an example of a communication concerning solitary confinement that led to a finding that both arts 7 and 10(1) had been violated following six months of solitary confinement see Human Rights Committee, Views: Communication No 123/1982, UN Doc CCPR/C/21/D/123/1982 (25 March 1983) ('Lluberas v Uruguay'). 
more than 15 days. The complainant submitted that on some occasions she was released for a couple of hours after 15 days, before being put back in isolation. ${ }^{23}$

Access to medical care is an important matter considered by TMBs and there are two different aspects to this, both of which are problematic in Australia. The first is provision of adequate medical care and the second is where prison is an inappropriate environment because of either mental illness or disability.

\section{Adequate Medical Care}

There have not been any HR Committee cases concerning the provision of medical care in Australian prisons. However, there have been complaints concerning the development of mental illness as a result of prolonged immigration detention that highlight Australia's obligations in relation to people's mental health while in the custody of the state. The HR Committee's view in response to one of these communications was that the continued detention of the author when the State party was aware of the author's mental condition and failed to take the steps necessary to ameliorate the author's mental deterioration constituted a violation of his rights under article 7 of the Covenant'. ${ }^{24}$

The views of TMBs in relation to inadequate medical care in prisons overseas is also illuminating. A complainant to the HR Committee from Kazakhstan was denied medical care and medication for more than a year, and not allowed access to his wheelchair while imprisoned. ${ }^{25}$ He was unable to move without assistance and the prison authorities did not provide him with assistance for him to perform even 'basic needs. ${ }^{26}$

23 Ibid [2.11]. As with many such communications there were a lot of other relevant circumstances that led to the finding that art 7 had been violated. In this communication, they included that the complainant had been gang raped while in state custody (see [2.3]) and had had her uterus removed without her consent (see [2.12]). For a discussion of the European Court of Human Rights consideration of solitary confinement see Bernadette Rainey, Elizabeth Wicks and Clare Ovey, Jacobs, White and Ovey. The European Convention on Human Rights (Oxford University Press, $7^{\text {th }}$ ed, 2017) 207-8.

24 Human Rights Committee, Views: Communication No 900/1999, UN Doc CCPR/C/76/D/ 900/1999 (13 November 2002) ('C v Australia') [8.4]. See also Human Rights Committee, Views: Communication No 1324/2004, UN Doc CCCPR/C/88/D/1324/2004 (31 October 2006) ('Danyal Shafiq $v$ Australia').

25 Human Rights Committee, Views: Communication No 2146/2012, UN Doc CCPR/C/119/D/ 2146/2012 (21 March 2017) ('Suleimenov v Kazakhstan') [2.5], [5.5].

26 Ibid [8.7]. 
The HR Committee found that he had not been treated with humanity and respect, in violation of art 10(1) of the ICCPR, and that art 7 of the ICCPR had also been violated. ${ }^{27}$

Another example comes from a communication to the HR Committee from a complainant from Sri Lanka. There were two aspects to the inadequate provision of medical treatment. The first was that he was experiencing chest pains. A doctor said he needed to be admitted to hospital, but the prison staff refused this. The doctor prescribed medication for the chest pains, but this was not provided to him by the prison staff. The second was that the complainant was a diabetic and was refused access to his diabetes medication while imprisoned. ${ }^{28}$ Along with other ill-treatment experienced by the complainant, this contributed to the finding by the HR Committee that art 7 of the ICCPR had been violated. ${ }^{29}$

\section{Prison an Inappropriate Environment}

The indefinite detention of an Australian who was unfit to stand trial because of their disability has been the subject of three communications to the Committee on the Rights of the Persons with Disabilities (Disabilities Committee) (the TMB responsible for interpreting the Convention on the Rights of Persons with Disabilities (CRPD)). In response to all three communications, the Disabilities Committee found that Australia violated a number of articles in the CRPD, but most relevantly for the purposes of this discussion, art 15 that prohibits TCID. ${ }^{30}$ Particular attention will be given to the communication by $\mathrm{Mr}$ Noble because the Australian

\footnotetext{
27 Ibid [8.7]-[9].

28 Human Rights Committee, Views: Communication No 2412/2014, UN Doc CCPR/C/118/D/ 2412/2014 (28 October 2016) ('Samathanam v Sri Lanka') [2.13].

29 Ibid [6.2]. Other ill-treatment included being beaten and being forced to watch others being beaten: at [2.8]-[2.9]. For further discussion of the HR Committee's views in relation to medical treatment see Alex Conte, 'Security of the Person' in Alex Conte and Richard Burchill (eds), Defining Civil and Political Rights. The Jurisprudence of the United Nations Human Rights Committee (Routledge, $2^{\text {nd }}$ ed, 2016) 128-9. For a discussion of the European Court of Human Rights consideration of medical care in prisons see Rainey, Wicks and Ovey, above n 23, 208-10.

30 Committee on the Rights of Persons with Disabilities, Views: Communication No 7/2012, UN Doc CRPD/C/16/D/7/2012 (15 August - 2 September 2016) ('Noble v Australia') [9]. Australia was also held to have violated arts 5(1), 12, 13, 14(1)(b) and 14(2) of the CRPD: Committee on the Rights of Persons with Disabilities, Views: Communication No 17/2013, UN Doc CRPD/C/22/D/17/2013 (30 August 2019) ('Leo v Australia') [8.10]. Australia was also held to have violated arts 5, 12, 13 and 14 of the CRPD: Committee on the Rights of Persons with Disabilities, Views: Communication No 18/2013, UN Doc CRPD/C/22/D/18/2013 (30 August 2019) ('Doolan v Australia') [8.10].
} 
Government has responded to the views of the Disabilities Committee, whereas there has been no response to the Committee's views in relation to the communications by $\mathrm{Mr}$ Leo and Mr Doolan.

Mr Noble was charged with 'sexual penetration of a child under the age of 13' and related charges when he was aged 19 in $2001 .{ }^{31}$ A court found that Mr Noble was 'unfit to stand trial' due to his 'intellectual disability' and inability to understand the charges. ${ }^{32} \mathrm{Mr}$ Noble nevertheless spent more than 13 years in prison, even though he would likely have served less than three years in prison if he had been tried and convicted. ${ }^{33}$

The conditions that $\mathrm{Mr}$ Noble were subjected to in prison and that contributed to the Disabilities Committee's findings of a violation of art 15 were directly related to his disability. The other component of the Committee's finding of a violation was the indefinite nature of Mr Noble's detention. The Committee's comments are relevant to how the Subcommittee for the Prevention of Torture and Other Cruel, Inhuman or Degrading Treatment or Punishment (SPT) may view the circumstances of other people in similar situations to Mr Noble when they visit Australian prisons as part of their role under the OPCAT. This is why the Disabilities Committee's findings on this point will be extracted in full:

[T] he Committee notes the author's [Mr Noble's] allegations that he was subjected to frequent acts of violence and abuse, that his disability prevented him from protecting himself against such acts, and that the State party authorities did not take any measures to sanction or prevent them or to protect the author therefrom. Additionally, the Committee notes that the author was detained for more than 13 years, without having any indication as to the duration of his detention. His detention was deemed indefinite in so far as, in compliance with section 10 of the Mentally Impaired Defendants Act, 'an accused found under this part to be not mentally fit to stand trial is presumed to remain not mentally fit until the contrary is found'. Taking into account the irreparable psychological effects that indefinite detention may have on the

31 Ibid [2.1].

32 Fiona McGaughey et al, 'UN Decision on Marlon Noble Case: Imprisonment of an Aboriginal Man with Intellectual Disability Found Unfit to Stand Trial in Western Australia' (2017) 42(1) Alternative Law Journal 67, 67.

33 Initially 10 years and three months, then another three years in civil detention in the same prison: see Noble v Australia, UN Doc CRPD/C/16/D/7/2012, [2.4], [2.8]. 
detained person, the Committee considers that the indefinite detention to which he was subjected amounts to inhuman and degrading treatment. The Committee therefore considers that the indefinite character of the author's detention and the repeated acts of violence to which he was subjected during his detention amount to a violation of article 15 of the Convention by the State party. ${ }^{34}$

The government's response to the Disabilities Committee's findings about the treatment of Mr Noble was dismissive. Freckelton and Keyzer describe the response as 'obdurate'. ${ }^{35}$ This is unsurprising in light of the discussion in Chapter 2 about Australia's typical response to the views of TMBs. The response emphasises that Mr Noble did not provide evidence of the violence and abuse that he was subjected to and, therefore, the allegations should not have been admissible. ${ }^{36}$ The response goes on to note that the government considers that the treatment 'does not meet the high threshold of harm required' and the Disabilities Committee should have applied a higher threshold. ${ }^{37}$ This is disrespectful of the Disabilities Committee as the TMB responsible for interpreting the CRPD.

The timing of the government's response is significant. It was released in October 2017, ${ }^{38}$ less than a year after the November 2016 release of a Senate Committee report on the subject of indefinite detention of people with cognitive and psychiatric impairment' that had been prompted by a 2015 Senate Committee inquiry into 'violence, abuse and neglect against people with disability in institutional and residential settings'. The Senate Committee recommended a Royal Commission on this topic. ${ }^{39}$ A Federal Royal Commission into 'Violence, Abuse, Neglect

34 Ibid [8.9].

35 Ian Freckelton and Patrick Keyzer, 'Fitness to Stand Trial and Disability Discrimination: An International Critique of Australia' (2017) 24(5) Psychiatry, Psychology and Law 770, 781.

36 Response of the Australian Government to the Views of the Committee on the Rights of Persons with Disabilities in Communication No 7/2012 (Noble v Australia) [17]-[19].

37 Ibid [58].

38 The Attorney-General's Department does not date the responses, but Freckelton and Keyzer note they accessed the article on 20 October 2017: Freckelton and Keyzer, above n 35, 782 n 23.

39 Senate Community Affairs References Committee, Indefinite Detention of People with Cognitive and Psychiatric Impairment in Australia (2016); Senate Standing Committee on Community Affairs, Violence, Abuse and Neglect Against People with Disability in Institutional and Residential Settings, Including the Gender and Age Related Dimensions, and the Particular Situation of Aboriginal and Torres Strait Islander People with Disability, and Culturally and Linguistically Diverse People with Disability (November 2015). See also Parliament of Victoria Family and Community Development Committee, Inquiry into Abuse in Disability Services Final Report (May 2016). 
and Exploitation of People with Disability' commenced in early 2019, which underscores the seriousness of the concern about the treatment of people with disabilities. ${ }^{40}$

The government's response, that there was insufficient evidence of violence and abuse that $\mathrm{Mr}$ Noble was subjected to, flies in the face of the evidence heard and accepted by both of these Senate Committee inquiries and the establishment of a Royal Commission. It also belies the evidence of violence in prisons more generally and the under-reporting of such violence that was presented in Chapter 1, as well as, most relevantly, the violence against vulnerable people in prisons. Mr Noble fell into two such categories of vulnerability: he had a disability and he was accused (although never convicted) of child sex offences. ${ }^{41}$

\section{Problematic Practices in Australian Prisons}

Throughout this book there has been frequent reference to the reports of Australian monitoring bodies, such as prison inspectorates, Ombudsmen and human rights commissions, that have highlighted seriously concerning practices in Australian prisons across all jurisdictions. There are four themes that emerge that are of particular relevance to this prerequisite: (1) use of solitary confinement, (2) access to medical care, (3) strip searching of women and (4) disrespectful treatment, particularly of Indigenous people.

Much of the discussion that follows reveals what appears to be problematic conduct by staff. In fact, such conduct is often appropriate in a formal sense. In many instances, problems occur when staff are complying with departmental policies. They lack the necessary autonomy to act differently

40 The terms of reference refer to 'the extent of violence, abuse, neglect and exploitation experienced by people with disability in all settings and contexts', suggesting that prisons would be relevant to the inquiry: Royal Commission into Violence, Abuse, Neglect and Exploitation of People with Disability, Commonwealth Letters Patent (4 April, 2019) <https://disability.royalcommission.gov.au/ publications/commonwealth-letters-patent>.

41 In relation to the heightened risk of violence against people with disabilities see Human Rights Watch, 'I Needed Help, Instead I Was Punished': Abuse and Neglect of Prisoners with Disabilities in Australia (2018). In relation to the heightened risk of violence directed to people convicted of child sexual abuse offences see Dot Goulding, 'Violence and Brutality in Prisons: A West Australian Context' (2007) 18(3) Current Issues in Criminal Justice 399, 407. 
in the circumstances. This is a major problem. Policies too often do not promote any duty upon staff to act consistently with international human rights law. If change is to occur, it is crucial that laws, policies and individual behaviour all undergo a fundamental shift.

\section{Solitary Confinement}

As outlined above, the HR Committee has noted that 'prolonged solitary confinement of the detained or imprisoned person may amount to acts prohibited by article 7' (that is, TCID). ${ }^{42}$ Mandela Rule 44 provides definitions of 'solitary confinement' and 'prolonged solitary confinement' as follows: 'solitary confinement shall refer to the confinement of prisoners for 22 hours or more a day without meaningful human contact. Prolonged solitary confinement shall refer to solitary confinement for a time period in excess of 15 consecutive days'.

Examples of solitary confinement from Tasmania and Queensland are discussed elsewhere in the book, but different instances are useful to the present analysis. ${ }^{43}$ The Victorian Supreme Court has made several comments about the adverse effects of holding people in prolonged solitary confinement in the Acacia Unit at the Barwon maximum security prison, with one judge visiting the unit to see for themselves the conditions in which people were being kept. ${ }^{44}$ In this particular unit, imprisoned people are kept in solitary confinement in their cells for 23 hours per day, meeting the definition of 'solitary confinement' in the Mandela Rules. ${ }^{45}$

In 2008, Bongiorno J ruled that a number of remandees who were being tried for complex terrorism offences could not receive a fair trial due to the combination of solitary confinement and inability to consult their legal representatives in the lead-up to the trial, the distance they were being transported from Barwon to the Supreme Court on a daily basis (approximately $60 \mathrm{~km}$ each way) and the strip searching and shackling

42 United Nations Human Rights Committee, above n 12, [6].

43 Pickett $v$ The State of Tasmania [2011] TASSC 907 (20 April 2011) (discussed in Chapter 3). The conditions in the Woodford supermax prison regime in Queensland are discussed in Chapters 3 and 8. For a South Australian example see Ombudsman South Australia, Department for Correctional Services - Unjust and Oppressive Separation of a Prisoner (2017).

44 R Benbrika and Others (No 20) (2008) 18 VR 410, 418.

45 Ibid. 
they were subjected to. ${ }^{46}$ The Court heard evidence from a forensic psychiatrist about the conditions at Acacia that included that they would cause 'a very significant degree of psychological and emotional distress'. ${ }^{47}$

In 2009, the Victorian Supreme Court accepted that the Acacia Unit was likely to cause psychological illness and this was found to be a breach of the Charter of Human Rights and Responsibilities Act 2006 (Vic) ('Charter') s 22(1) requirement that people be treated with humanity and respect. The Court found that:

[t]o place people in a custodial environment which is able to be foreseen as likely to result in their suffering a major psychiatric illness can hardly be said to be treating them with humanity. This is particularly so if, as here, no cogent grounds have ever been put forward as justifying such conditions for these prisoners. ${ }^{48}$

Psychological harm was also caused by the conditions in the Acacia Unit to Mr Dale. Mr Dale was remanded in custody in the unit from 27 February until 2 September 2009 and was being kept there for his own protection because he was a former police officer. ${ }^{49}$ This is a period of six months, which definitely meets the Mandela Rules definition of 'prolonged' solitary confinement. Following this period (at the time of his bail application), he was 'suffering from a "moderate to severe" mental illness' and the Court opined that the conditions under which he had been held 'can cause significant psychological harm, and can do so quite quickly. Once the risk of such harm is identified, great care should be taken to prevent it eventuating, unless there is a compelling need for such repressive conditions to be maintained'.$^{50}$

The final example from the Acacia Unit relates to Mr Tiba who was also on remand in the unit for two and a half years prior to being sentenced (from July 2011 to December 2013). The County Court accepted that Mr Tiba was subject to solitary confinement, which had caused 'a high degree of psychological disturbance, resulting in the clinical depression'. The Court noted that the Charter requirement that people be treated with

46 Ibid 428-9. The Court went on to stipulate the alterations that would need to be made before the trial could continue: at 430-1. For further analysis of this decision see Matthew Groves, 'Editorial: Prison Conditions and the Right to a Fair Trial' (2008) 32 Criminal Law Journal 133.

47 Ibid 422.

$48 \quad R v$ Kent [2009] VSC 375, [32].

49 Dale v DPP [2009] VSCA 212 (21 September 2009), [34].

50 Ibid [35]. 
humanity and respect was a relevant consideration, but did not make a finding as to whether it had been breached (although the Court did reduce the penalty imposed). ${ }^{51}$

The Victorian Courts have not considered whether solitary confinement in the Acacia Unit constitutes TCID under s 10 of the Charter. The Victorian Ombudsman has considered this in the context of an OPCAT-compliant inspection of the Dame Phyllis Frost Centre in Victoria. The report examined the conditions in an isolation unit where women were being kept locked in their cells for 22-23 hours per day, without access to fresh air daily, and where several women had been kept for more than a year. ${ }^{52}$ The Ombudsman reported that this long-term separation may 'amount to treatment that is cruel, inhuman or degrading under the Charter and is incompatible with the Nelson Mandela Rules'.53 This is something that will need to be considered in more detail as part of OPCAT compliance.

Human Rights Watch recently conducted an examination of the treatment of people with disabilities in prisons in Western Australia (WA), Queensland and New South Wales (NSW) between September 2016 and January 2018. They found many instances of people being kept in solitary confinement, sometimes without access to toilets, with one woman confined for 28 days having to 'use cardboard urine test containers' because of the lack of a toilet. ${ }^{54}$ They reported multiple instances of people with disabilities who had been in solitary confinement for years at a time-in one instance, 19 years. ${ }^{55}$ A Queensland psychologist told Human Rights Watch that '[i]n some cases, they are punished for behavior related to their disability. It's a systemic issue, there should be an alternative'. ${ }^{56}$ Unsurprisingly, given the medical evidence before the Victorian courts about the effects of solitary confinement, the report noted that ' $[\mathrm{i}] \mathrm{n}$ most solitary confinement cases that Human Rights Watch documented, people with disabilities ... said their psychological condition deteriorated after spending time in the sterile and isolating environment of solitary confinement units..$^{57}$

51 DPP v Tiba \& Ors [2013] VCC 1075, [30]-[31].

52 Victorian Ombudsman, Implementing OPCAT in Victoria: Report and Inspection of the Dame Phyllis Frost Centre (2017) 52, 56.

53 Ibid 57.

54 Human Rights Watch, above n 41, 5.

55 Ibid 43.

56 Ibid.

57 Ibid 51. 
This treatment is clearly in violation of international human rights law both because of its prolonged nature and because of Mandela Rule 45(2) which states, '[ $t$ ] he imposition of solitary confinement should be prohibited in the case of prisoners with mental or physical disabilities when their conditions would be exacerbated by such measures'.

\section{Access to Medical Care}

People in prison tend to have poorer health than the general population, and people with mental illness or disability are over-represented (as documented in Chapter 1). These statistics indicate that most people in prison are likely to have health needs (physical and/or mental) that must be addressed while they are incarcerated.

The absence of adequate medical care violates a number of Australia's human rights obligations, most obviously the right to health found in art 12 of the International Covenant on Economic, Social and Cultural Rights. ${ }^{58}$ It provides that ' $[\mathrm{t}]$ he States Parties to the present Covenant recognize the right of everyone to the enjoyment of the highest attainable standard of physical and mental health'. ${ }^{59}$ People in prison also have a right to medical care of an equivalent standard to that provided to people in the general community pursuant to Principle 9 of the Basic Principles for the Treatment of Prisoners, which provides that '[p]risoners shall have access to the health services available in the country without discrimination on the grounds of their legal situation'. ${ }^{60}$ Inadequate medical care may constitute TCID, or failure to treat the person with humanity and respect, as seen from the discussion of individual communications earlier in this chapter.

In Australian prisons, the problem tends to be either inadequate health care provision, or keeping people in prison inappropriately because they should be in a specialised facility, such as a mental health hospital, to receive the treatment they require. Examples of both problems have arisen.

58 International Covenant on Economic, Social and Cultural Rights, opened for signature 16 December 1966, 999 UNTS 3 (entered into force 3 January 1976).

59 The Treaty was signed by Australia on 10 March 1976, but this Article has not been incorporated into domestic law.

60 Mandela Rule 24(1) provides a similar requirement: 'Prisoners should enjoy the same standards of health care that are available in the community, and should have access to necessary health-care services free of charge without discrimination on the grounds of their legal status'. The Australian Capital Territory has passed legislation to incorporate this principle: CMA s 53(1)(a). 
The issue of lack of treatment for a mental health condition calls into question whether the detention is lawful, as required under art 9 of the ICCPR. This article provides that '[e]veryone has the right to liberty and security of person. No one shall be subjected to arbitrary arrest or detention. No one shall be deprived of his liberty except on such grounds and in accordance with such procedure as are established by law'. In essence, the legal position is that imprisonment becomes arbitrary if a person is being detained because of their mental illness. This is because prisons are not a therapeutic environment.

\section{Inadequate Medical Care}

There are some particularly shocking examples of imprisoned peopleparticularly women-being provided with inadequate medical care in prisons. These examples are additional to the other systemic problems referred to in earlier chapters, such as overcrowding causing people to be transferred frequently, which impacts on their medical care, and the problems connected with physical conditions that will be discussed in Chapter $8 .^{61}$

On 11 March 2018, a woman gave birth in her prison cell in the Bandyup Women's Prison in WA. The Office of the Inspector of Custodial Services (OICS) report into this incident referred to it as 'a distressing, degrading and high risk set of events'. ${ }^{62}$ The OICS made a number of findings, but the overarching finding was that there was 'no justification' for what occurred and that it resulted from 'cascading and intersecting failures. ${ }^{63}$ These failings may be divided into infrastructure and human failings.

The infrastructure failings include inadequate accommodation for pregnant women in WA. Corrections in WA has reportedly ignored earlier recommendations by the OICS about these inadequacies. ${ }^{64}$ There are also inadequate medical facilities in the particular prison, which resulted in the woman being returned to her cell after she had indicated she was going into labour. ${ }^{65}$

61 See, eg, Australian Institute of Health and Welfare, The Health of Australian Prisoners 2018 (2019) 7. See also the discussion in Chapters 1 and 4.

62 Office of the Inspector of Custodial Services (OICS), The Birth at Bandyup Women's Prison in March 2018. Inspector's Summary (2018) 1. The Inspector only released a summary of findings because releasing the full report would have compromised the privacy of the woman concerned. The full report was provided to the Minister for Corrective Services and other Western Australian government agencies: at 2 .

63 Ibid 4, 2.

64 Ibid.

65 Ibid 1,3 . 
The human failings are as follows. What the OICS described as 'poor communication' could also be described as failure to listen to, and believe, the woman when she said she was in labour. ${ }^{66}$ She indicated this at $5.30 \mathrm{pm}$, was returned to her cell at $6 \mathrm{pm}$ for the night time 'lock down', and the baby was born at $7.40 \mathrm{pm} .{ }^{67}$ She should have been transferred to a hospital at $5.30 \mathrm{pm}$ (if not in the preceding days, well in advance of her labour).

Once in the cell and the staff accepted that she was in labour, the OICS noted that staff were slow to respond. It took one hour for the nursing staff to arrive. When they arrived, they could not enter the locked cell because a person at the gatehouse ('a 2-3 minutes walk away') had the keys. After the baby was delivered (with staff outside the door), it took 7-12 minutes before the cell door was opened. The OICS noted it was 'inexplicable that nobody called a Code Red emergency until' this point. ${ }^{68}$ Disturbingly, the OICS found that staff were 'desensitised' to the needs of this woman and of other women in the prison, something that they had drawn attention to in previous reviews. ${ }^{69}$

The OICS also considered the impact that this incident had on other women in the prison. They found that it had 'generated understandable fear on the part of prisoners that medical emergencies at Bandyup will not result in a proper response..$^{70}$

This situation was a clear violation of Mandela Rule 27, which provides that '[a]ll prisons shall ensure prompt access to medical attention in urgent cases. Prisoners who require specialized treatment or surgery shall be transferred to specialized institutions or to civil hospitals'. The Institute for Criminal Policy Research's Handbook for Prison Staff notes that pregnant women should preferably not even be in prison, but if they are, ' $[t]$ he presumption should always be that no expectant mother will give birth inside a prison'. ${ }^{71}$

\footnotetext{
66 Ibid 3.

67 Ibid 1.

68 Ibid 1, 3 .

69 Ibid 3. In 2003, the Inspector described Bandyup as in a sense a male prison occupied by females. Security ratings accord with male criteria; staffing is predominantly by male officers; the role of women as mothers is inadequately recognised': OICS, Report of an Announced Inspection of Bandyup Women's Prison June 2002 (2003) 6.

70 Ibid 4.

71 Andrew Coyle and Helen Fair, A Human Rights Approach to Prison Management. Handbook for Prison Staff (Institute for Criminal Policy Research Birkbeck, University of London, $3^{\text {rd }}$ ed, 2018) 150.
} 
Policy, as foreshadowed above, is sometimes the cause of breaches. The South Australian Department of Correctional Services introduced a policy in early 2011 that all imprisoned people receiving medical treatment in hospital have their legs shackled together, in addition to having one arm and one leg shackled to the hospital bed. ${ }^{72}$ This policy was still in force in $2017 . .^{73}$ The policy applies to women giving birth and to people receiving end-of-life care. ${ }^{74}$

This policy is a flagrant breach of international law, with Mandela Rule 48(2) providing, '[i]nstruments of restraint shall never be used on women during labour, during childbirth and immediately after childbirth'; a rule that is repeated in identical terms in Rule 24 of the Bangkok Rules. As a point of comparison, the European Court of Human Rights (ECtHR) found a violation of human rights in an instance where a women was shackled while in the maternity hospital except for when she was in labour (that is, before and after delivery of the baby). ${ }^{75}$ The Court noted, '[a]ny risk of her behaving violently or attempting to escape would have been hardly imaginable given her condition'; ${ }^{76}$ that the 'unjustified shackling continued after the delivery, when she was particularly sensitive'; and that this constituted 'inhuman and degrading treatment'. ${ }^{7}$

This policy has been investigated by the South Australian Ombudsman on a number of occasions. In relation to women giving birth, the Ombudsman's investigation found that ' $[\mathrm{t}]$ he restraints are only removed during the active stage of labour and are secured again immediately after the birth of the baby'. ${ }^{78}$ The Ombudsman was also highly critical of male prison staff guarding women while they are in hospital and being in the room while they are in labour. ${ }^{79}$ The Ombudsman drew a parallel to when a female imprisoned person is being searched. They are entitled under the Correctional Services Act 1982 (SA) to be searched by a staff member of

72 The introduction of this policy followed the escape of three imprisoned people in 2010: Ombudsman South Australia, Ombudsman Investigation into the Department for Correctional Services in Relation to the Restraining and Shackling of Prisoners in Hospitals (2012) 1.

73 The policy was applied in the case investigated by the Ombudsman in 2017: Ombudsman South Australia, Department for Correctional Services - Unlawful Shackling of a Mental Health Patient in Hospital (2017).

74 Ombudsman South Australia, above n 72, 1.

75 Korneykova and Korneykov v Ukraine [2016] ECHR 56660/12, [14].

76 Ibid [112].

77 Ibid [113], [115].

78 Ombudsman South Australia, Ombudsman Investigation into the Department of Correctional Services in Relation to the Restraining and Shackling of Prisoners in Hospitals (2012) 28.

79 Ibid 28-9. 
the same sex. The Ombudsman therefore concluded that the same criteria should apply when women are being guarded while 'undergoing medical procedures relating to childbirth'. ${ }^{80}$

The Ombudsman's overall finding was that the blanket application of the shackling policy-that is, application without regard to the dangerousness of the individual, or the risk of their escape-was contrary to the requirement to maintain the dignity of imprisoned people. ${ }^{81}$ The Ombudsman recommended that '[p]regnant women should never be restrained during labour'. ${ }^{82}$

The Ombudsman has also commented on the effect the shackling policy is having on imprisoned people's willingness to access medical treatment more generally:

[I]t is common for prisoners to refuse medical treatment. This is because the prisoners (particularly low risk prisoners) do not wish to face the humiliation and shame of attending medical facilities amongst the general public in prison clothing and shackles. ${ }^{83}$

A barrier to the provision of adequate health care that applies across every state and territory is that the Commonwealth Government does not provide any funding for prison health services through the Medicare Benefits Schedule (MBS), or medication through the Pharmaceutical Benefits Scheme (PBS). Funding is left to state and territory governments, which means that 'provision of services that would attract MBS and PBS rebates in the community [become] too expensive to offer at scale in prisons ${ }^{8}{ }^{84}$ Several peak medical bodies have called for this exclusion to end. ${ }^{85}$

80 Ibid 28.

81 Ibid 36.

82 Ibid 3, Recommendation 5. The Victorian Ombudsman has also reported that women in the Dame Phyllis Frost Centre are being shackled when attending medical appointments: Victorian Ombudsman, above n 52, 51.

83 Ombudsman South Australia, above n 78, 37. See also the Ombudsman's report about inadequate medical care for a diabetic: Ombudsman South Australia, Department for Correctional Services - Handling of a Prisoner's Diabetes (2018).

84 Craig Cumming et al, 'In Sickness and in Prison: The Case for Removing the Medicare Exclusion for Australian Prisoners' (2018) 26 Journal of Law and Medicine 140, 148-9.

85 Such as the Australian Medical Association and the Public Health Association of Australia: ibid 149. 


\section{Prison an Inappropriate Environment}

There are two main categories of imprisoned people for whom prison is an inappropriate environment. The first is those who have not been convicted of a criminal offence because they are either unfit to stand trial or found not guilty by reason of mental impairment. The second is those who have been sentenced to imprisonment, but are mentally ill and have needs that cannot be catered for in the prison setting. Both are problems in Australian prisons.

As noted earlier in this chapter, the Disabilities Committee has expressed views about the indefinite detention of $\mathrm{Mr}$ Noble in WA and Mr Leo and Mr Doolan in the Northern Territory (NT), all of whom were unfit to stand trial due to their disabilities. WA and the NT are not the only Australian jurisdictions that indefinitely imprison people unfit to stand trial. This was the topic of a Senate Committee report in November 2016. The report noted that indefinite detention is possible in Victoria, in addition to the NT and WA. ${ }^{86}$ The evidence before the Senate Committee was that there are approximately 100 people indefinitely detained nationally, and that 50 of them are Indigenous. ${ }^{87}$

The Senate Committee was of the view that it is inappropriate for forensic patients to be placed in prisons. They noted their concern about 'the lack of therapeutic support in this environment' and that it 'unnecessarily exposes them to physical risk and to isolation, both within the prison and from the community' ${ }^{88}$ The Senate Committee's preference was for people to be housed in 'secure care facilities and supported accommodation in the community' and they made two recommendations to support this. ${ }^{89}$

An example of a person found not guilty on grounds of mental impairment that should not have been in prison, but was imprisoned anyway, comes from Victoria. Mr White was found not guilty of murder on the grounds of mental impairment and the Court heard that it would be appropriate for him to be treated at the Thomas Embling Hospital. However, there was no bed available, so he was being held in prison. Bongiorno J

86 Senate Community Affairs References Committee, above n 39, 14.

87 Ibid. The report gives a breakdown by jurisdiction: at 14-20.

88 Ibid 179.

89 Ibid 179-80, Recommendations 19 and 20. 
opined that 'his continued incarceration in a prison would appear to be contrary to the spirit, if not the letter of the Charter of Human Rights and Responsibilities'..$^{90}$

The other category of people for whom prison is an inappropriate environment is those who have been sentenced to imprisonment, but have complex needs. The South Australia Ombudsman investigated one such instance. A woman who had repeatedly self-harmed had been restrained for 22 hours per day for a period of eight months as a way of managing her behaviour. ${ }^{91}$ The Ombudsman found that the complainant presented with complex needs that are best dealt with outside of a custodial setting, and that a prison is not a therapeutic environment'. ${ }^{2}$

The NSW Coroner investigated another instance. Mr Simpson had paranoid psychosis and was placed in isolation in Goulburn Correctional Centre and provided with minimal psychiatric care. ${ }^{93}$ The health professionals who did see Mr Simpson strongly advocated for him to be moved to a hospital. ${ }^{94} \mathrm{Mr}$ Simpson was later moved to the Long Bay correctional centre, where he was again kept in isolation. He was diagnosed with paranoid schizophrenia and medical professionals again recommended that he be hospitalised.

One doctor who gave evidence before the Coronial Inquest said, 'I have never had a higher index of concern about a patient. I felt powerless because it was absolutely apparent that he needed to be cared for in hospital and this was not happening. ${ }^{95}$ There was also evidence that the solitary confinement was making Mr Simpson's mental illness worse. ${ }^{96}$ Mr Simpson ultimately hanged himself in his cell. ${ }^{97}$

\section{Strip Searching of Women}

This section on problematic practices in Australian prisons focuses specifically on women. While strip searching exacerbates many of the vulnerabilities of the female prison population referred to in Chapter 1,

$90 \quad R v$ White [2007] VSC 142, [4].

91 Ombudsman South Australia, Final Report Department of Correctional Services (2013) 16-17.

92 Ibid 16.

93 Magistrate Pinch, Inquest into the Death of Scott Ashley Simpson, 2006 [8].

94 Ibid [8]-[9].

95 Ibid [11].

96 Ibid [16].

97 Ibid [12], [19]. 
this is not to downplay the humiliation that may be experienced by imprisoned men subjected to strip searching. ${ }^{98}$ Mandela Rule 52 requires that strip searching only be used 'if absolutely necessary' in recognition of this universal detrimental impact. International law has nevertheless recognised that strip searching is more traumatising for imprisoned women than imprisoned men. This has resulted in the introduction of Rule 20 of the Bangkok Rules, which requires alternative search methods to be developed so as 'to avoid the harmful psychological and possible physical impact of invasive body searches'.

In light of this international position, it is particularly concerning that in 2014 the Queensland Ombudsman documented a policy being applied at the Townsville Women's Correctional Centre whereby 'women taking a certain type of medication were strip searched both before and after the medication was provided for a period of 7 months. Some women were taking the medication twice per day and were therefore strip searched four times per day'. ${ }^{99}$ The Queensland Ombudsman reported that this policy had a negative impact on the women subject to it, and some chose to come off the medication to avoid being strip searched. ${ }^{100}$ The Ombudsman found it was 'intrusive', adversely impacted on the dignity of the women and was not justified, particularly because alternative less invasive measures (such as urine testing) could have achieved the intended aims. ${ }^{101}$

A 2017 Tasmanian Ombudsman investigation into strip searching raised concerns relating to a lack of clarity surrounding Tasmanian Prison Service's policy (as set out in a Director's Standing Order). The Ombudsman received a report that two women who did not comply with the request to be strip searched (in separate incidents) were searched by four staff in the Hobart Reception Prison. In one instance, two of the staff were male, and in the other, three were male. ${ }^{102}$ The Ombudsman did not have any concerns with how strip searches were conducted when

98 For a recent detailed examination of strip searching of males and females in WA prisons see OICS, Strip Searching Practices in Western Australian Prisons (2019).

99 Anita Mackay, 'The Relevance of the United Nations Mandela Rules for Australian Prisons' (2017) 42(4) Alternative Law Journal 279, 283.

100 Queensland Ombudsman, The Strip Searching of Female Prisoners Report. An Investigation into the Strip Search Practices at Townsville Women's Correctional Centre (2014) 15.

101 Ibid 16-17. See also the discussion of the Victorian Ombudsman's recommendation about strip searching in the Dame Phyllis Frost Centre in Chapter 3, and in Victorian Ombudsman, above n 52, 57-60, 103, Recommendation 5.

102 Ombudsman Tasmania, Investigation into the Strip Searching Procedures for Women at the Hobart Reception Prison (2017) 6. 
the imprisoned person complied, but found the policy relating to noncompliant searches and use of force was insufficiently clear, particularly as to how many staff were involved and whether only female staff were allowed to remove the clothing of female imprisoned people. ${ }^{103}$

The Tasmanian Prison Service had drafted a new Director's Standing Order that the Ombudsman considered had addressed some of these concerns. The Ombudsman also recommended that the prison service consider purchasing a body scanner, an approach taken by the Perth Watch House in response to an incident where a woman's finger was fractured during a strip search that involved force. ${ }^{104}$ The OICS has recommended that 'new technology' be used to reduce strip searching in WA prisons, but the WA Government did not accept this recommendation. ${ }^{105}$

The Alexander Maconochie Centre (AMC) in Canberra has a scanner and accompanying policy that provides guidelines for its use, including matters such as the maximum radiation limits for women and men. ${ }^{106}$ The ACT Human Rights Commission has reported that strip searching of women is being used minimally in the AMC, and when it does occur (usually on admission), it is never in the presence of a person of the opposite sex. ${ }^{107}$

A case decided by the ECtHR demonstrates that there may be two different human rights infringed by strip searching. The case involved the strip searching of a mother and her disabled son when they went to a prison in the UK to visit a family member. The ECtHR considered whether the strip searching violated the prohibition of TCID and the right to privacy. ${ }^{108}$

The ECtHR determined that a single strip search of these visitors did not constitute TCID. ${ }^{109}$ However, the Court did clarify that the circumstances in prisons that would meet the threshold for TCID included:

103 Ibid $12-15$.

104 Ibid 23-4.

105 OICS, above n 98, 29, 33.

106 Corrections Management (SOTER XRay Body Scanner) Policy 2010 (No 2).

107 ACT Human Rights Commission, Human Rights Audit on the Conditions of Detention of Women at the Alexander Maconochie Centre: A Report by the ACT Human Rights and Discrimination Commissioner (2014) 70.

108 The relevant provisions of the European Convention for the Protection of Human Rights and Fundamental Freedoms are arts 3 and 8 respectively. These rights are protected in Australia by ss 10 and 12 of the HRA, ss 10 and 13 of the Charter and ss 17 and 25 of the Human Rights Act 2019 (Qld). 109 Wainwright v United Kingdom [2006] ECHR 12350/04, [46]. 
- a search conducted by an officer of the opposite sex involving genitals being touched

- a search involving multiple officers who also verbally abused the person being searched

- when strip searching was being carried out in a 'systemic and long term' manner and could not be justified for maintenance of security and good order of the prison. ${ }^{110}$

The ECtHR made a finding that the strip searching of the visitors did violate their right to privacy because staff did not follow proper procedures. For example, the visitors were provided with a consent form to sign after the searches were carried out and when the son asked for his mother's help to read the form, this was refused. ${ }^{111}$ The ECtHR commented that 'it behoves the prison authorities to comply strictly with those safeguards and by rigorous precautions protect the dignity of those being searched from being assailed any further than is necessary'. ${ }^{112}$

This decision is helpful for establishing the legal principles that apply to strip searching, and particularly the parameters of TCID in this context, for the purposes of OPCAT compliance.

\section{Disrespectful Treatment}

Disrespectful treatment is the opposite of treatment with humanity and respect. Based on qualitative research conducted in Victorian and WA prisons, Naylor has analysed the views of imprisoned people about their experience of the absence of respect in prisons. A number of imprisoned people interviewed perceived that they are treated like animals by staff. Naylor describes the interview data as follows:

Many participants compared their treatment to that of animals, consciously or unconsciously illustrating the contempt they perceived.

[T] hat's basically why they treat everyone like an animal. (prisoner 1)

Some of the crap you wouldn't feed your dog. (prisoner 2)

110 Ibid [42] referring to previous decisions of the European Court of Human Rights including Valasinas v Lithuania [2001] ECHR 44558/98, Iwańczuk v Poland [2001] ECHR 25196/94 and Van der Ven $v$ the Netherlands [2003] ECHR 50901/99.

111 Wainwright v United Kingdom [2006] ECHR 12350/04, [13], [15], [35], [45], [49].

112 Ibid [48]. 
[Talking about meal times] ... pushing through like cattle through the dining hall. (prisoner 3)

You couldn't put animals in a place like that. (prisoner 4). ${ }^{113}$

Interviewees also referred to a lack of understanding of Indigenous culture by staff. An example of this is 'prisoners who are elders being shouted at and put on show, particularly by female officers, in front of younger Indigenous persons'. This was raised as an instance of a lack of acknowledgement of the respect normally accorded to elders in Indigenous culture. ${ }^{114}$

In addition, interviewees raised concern about the way staff treated them in front of family when they came to visit. ${ }^{115}$ For instance, they reported 'instances where they were shouted at for touching, or getting out of their seat, sometimes when they were unaware of the applicable rules'. ${ }^{116}$

A study carried out by the OICS made similar findings, as follows:

Surveys ... across 13 prisons in WA between early 2010 and late $2012 \ldots$ found that $46.8 \%$ of respondents 'felt that prison officers did not treat prisoners with dignity'. This view was more widely held amongst Indigenous people, with only $28.5 \%$ of Indigenous respondents indicating that they were treated with dignity by staff, compared to $41.1 \%$ of non-Indigenous respondents; (with $41.1 \%$ still being a low proportion). A further $53.7 \%$ of Indigenous respondents indicated that 'staff neither respected not understood their culture'. ${ }^{117}$

Human Rights Watch documented a lot of disrespectful treatment directed towards imprisoned people with disabilities, particularly Indigenous people. One man told Human Rights Watch the following: “'[An officer told me]: 'Why are you still living? It's time you die.' Officers are supposed to help us, not treat us like rubbish and run us down"' ${ }^{118}$ In relation to Indigenous people, the report documented the following:

In 11 out of 14 prisons, Human Rights Watch found evidence of staff and prisoners expressing racism in language and behavior towards Aboriginal and Torres Strait Islander prisoners. Racism in

113 Naylor, above n 4, 110.

114 Ibid.

115 Ibid 101.

116 Ibid.

117 Mackay, above n 16, 379, referring to OICS, Prisoner and Staff Perceptions of WA Custodial Facilities from 2010-2012 (2014).

118 Human Rights Watch, above n 41, 34. 
prison can manifest itself in many forms, such as name-calling, racial slurs, verbal abuse, harassment, biased treatment, and at times violence. ... Some officers are racist: '[they call us] "black cunt," "sheep," "mother fucker" or "pricks."”119

Lack of sufficient staff training may be a contributing factor. The same study by the OICS referred to above found that staff felt they had received inadequate training in matters including 'managing people with mental health issues' or 'drug issues'. ${ }^{120}$ Approximately 70 per cent of staff working in the AMC also report feeling inadequately trained in these matters. ${ }^{121}$ As noted in Chapter 1, this is a large proportion of the Australian prison population. Human Rights Watch also noted a lack of training for identifying and dealing with people with disabilities. ${ }^{122}$ The next section undertakes further discussion about the need to improve training of prison staff.

There may also be perceptions held by staff that are not consistent with respectful or rights-respecting treatment. The same research project conducted by Naylor also interviewed prison staff. These interviews found that staff in both jurisdictions were wary about imprisoned people as 'rights-holders' and the impact that rights may have on security, with Naylor noting, "[ $t$ ] here seemed to be concerns that prisoners would label all claims, no matter how minor, as "rights issues" and that this would undermine management and security regimes'. ${ }^{123}$

In WA, some staff perceived that imprisoned people had in fact lost their human rights, which, as outlined in Chapters 2 and 5, is inconsistent with the international and Australian legal position. Naylor noted, ' $[s]$ ome WA staff instead saw the loss of rights as part of prisoners' punishment, and suggested that they should be given only the basic minimum of entitlements and/or should have to relinquish certain rights as a part of their punishment for committing a crime'. ${ }^{124}$

119 Ibid 35.

120 OICS, above n 117, 20.

121 ACT Inspector of Correctional Services, Report of a Review of a Correctional Centre by the ACT Inspector of Correctional Services: Healthy Prison Review of the Alexander Maconochie Centre (2019) 66.

122 Human Rights Watch, above n 41, 66.

123 Bronwyn Naylor, 'Researching Human Rights in Prisons' (2015) 4(1) International Journal for Crime, Justice and Social Democracy 79, 87.

124 Ibid. 


\section{Strategies for Improving Interactions Between Staff and Imprisoned People in Australian Prisons}

The problematic practices outlined earlier in this chapter need to be eradicated to achieve compliance with the prerequisite of staff treating imprisoned people in a human rights-consistent manner. It was noted prior to the discussion of these problematic practices that many of them stem from policies. Individual staff do not necessarily have the autonomy to act any differently. This is a matter that needs to be addressed by some of the macro-level prerequisites put forward in other chapters; those that address changes to law and the goals of imprisonment.

The specific strategies suggested for compliance with this prerequisite are instead focused on the actions of individual staff. They can be pursued alongside the macro-level prerequisites referred to in the previous paragraph. The three specific strategies are: (1) having the right leaders to drive the necessary reform, (2) comprehensive human rights-based training of prison staff and (3) ensuring the community value the work done by prison staff.

\section{Leadership}

Leadership in any organisation plays a pivotal role in setting the agenda and values that will apply within that organisation. This is even more so in hierarchical organisations, such as prisons, because everyone looks to the 'person at the top' for direction and to set the culture. ${ }^{125}$ Prison managers set out their expectations of staff and it is possible for such expectations to include human rights-consistent treatment of imprisoned people. It is not suggested here that this is easy to achieve, but an illustration will be given from a prison in India to show that leadership can be extremely powerful, even in prisons that operate on a far larger scale than Australian prisons.

Kiran Bedi is described by Taylor and Rynne as one of five 'idealistic prison managers' that 'braved the punitive tide to apply reformative principles'. ${ }^{126}$ Ms Bedi was put in charge of Tihar Central Prison in New Delhi for

125 Andrew Coyle, 'Governing, Leadership and Change' in Yvonne Jewkes (ed), Handbook on Prisons (Willan Publishing, 2007) 511.

126 A J W Taylor and John Rynne, 'Exemplary Prisoner Management' (2016) 49(4) Australian \& New Zealand Journal of Criminology 512, 512. 
two years from 1990. The facility was designed for 2,000 people but was imprisoning 9,000 people at the time Ms Bedi took over the management of the prison. ${ }^{127}$ Her aim was 'to create mutual respect between staff and inmates'. ${ }^{128}$ Strategies to implement this included carrying out 'daily inspections' and posting the expectations she had of staff on notice boards in full view of staff and imprisoned people. ${ }^{129}$ This aligns with Coyle's recommended approach for ensuring humane treatment in prisons which, he says, requires 'visible and consistent leadership'. ${ }^{130}$

Taylor and Rynne summarise the effects of Ms Bedi's leadership as follows:

Within 18 months Kiran Bedi converted the place into a relatively peaceful ashram in which open dialogue and problem solving were encouraged. She improved the morale and working conditions for the staff and introduced programmes to engage prisoners in education, crafts, horticulture, prayer, and meditation, and generally to help them take responsibility for improving their own lives. ${ }^{131}$

\section{Comprehensive Staff Training}

Earlier in this chapter there was some discussion about perceptions held by some prison staff that may be counterproductive to compliance with this prerequisite. This section considers how training might be used to achieve compliance, but it is first necessary to give a brief overview of the current training provided to prison staff. At present, it is not human rights focused.

Most corrective services departments operate their own training for new prison staff. Table 7.5 provides an overview of the duration of correctional staff training around Australia from the shortest to the longest.

127 Ibid 519.

128 Ibid.

129 Ibid 520.

130 Coyle, above n 125, 512.

131 Taylor and Rynne, above n 126, 519. An Australian example of human rights-committed leadership is the leadership when the Alexander Maconochie Centre (AMC) was opened in the Australian Capital Territory in 2009, which has been detailed elsewhere: see Anita Mackay, 'Operationalising Human Rights Law in Australia - Establishing a Human Rights Culture in the New Canberra Prison and Transforming the Culture of Victoria Police' in Bronwyn Naylor, Julie Debeljak and Anita Mackay (eds), Human Rights in Closed Environments (Federation Press, 2014) 282; Mackay, above n 16, 373-4. 
Table 7.5: Prison Staff Training Duration

\begin{tabular}{|l|l|}
\hline State/Territory & Duration of training for new staff \\
\hline Victoria & $\begin{array}{l}42 \text { days: equivalent to six weeks, with two of these weeks } \\
\text { described as 'on the job'132 }\end{array}$ \\
\hline New South Wales & 10 weeks $^{133}$ \\
\hline Queensland & 10 weeks $^{134}$ \\
\hline Australian Capital Territory & $\begin{array}{l}\text { Eight weeks: six weeks 'classroom based' and two weeks } \\
\text { 'on the job'135 }\end{array}$ \\
\hline Northern Territory & $\begin{array}{l}11 \text { weeks: eight weeks of training described as 'off the job' } \\
\text { followed by three weeks of 'on the job' training }\end{array}$ \\
\hline Western Australia & 12 weeks ${ }^{137}$ \\
\hline South Australia & 12 weeks ${ }^{138}$ \\
\hline Tasmania & 13 weeks ${ }^{139}$ \\
\hline
\end{tabular}

It is difficult to access information about the content of these training courses in most jurisdictions. For example, the NT Information Pack simply notes that ' $[\mathrm{d}]$ uring training recruits are required to establish and maintain an appropriate level of fitness and demonstrate an understanding of Correctional Centre practice and procedures'. ${ }^{140}$ The ACT flyer notes that the training covers topics including 'legislation and policies, report writing and managing detainees with challenging behaviours. ${ }^{141}$

132 Corrections Jobs, The Application Process <https://www.correctionsjobs.vic.gov.au/roles/prisons/ prison-officers/the-application-process $>$.

133 NSW Government, Careers in Justice NSW, Correctional Officer <http://www.careers.justice. nsw.gov.au/Pages/our-roles/corrections-careers/correctional-officer.aspx>.

134 Queensland Corrective Services, Work for $U_{s}<$ https://corrections.qld.gov.au/about-queenslandcorrective-services/work-for-us/>.

135 ACT Inspector of Correctional Services, above n 121, 67. The ACT Inspector of Correctional Services noted that this was reduced from 10 or 11 weeks recently.

136 Northern Territory Government, Department of Attorney-General and Justice, Correctional Officers <https://justice.nt.gov.au/correctional-services/corrections-careers/correctional-officers>.

137 Government of Western Australia, Department of Corrective Services, Prison Officer <https:// www.wa.gov.au/organisation/department-of-justice/prison-officer>.

138 Government of South Australia, Department for Correctional Services, Correctional Officer Recruitment Process <https:/www.corrections.sa.gov.au/careers/Working-with-prisoners-and-offenders/ roles/applying-to-be-a-correctional-officer>.

139 Tasmanian Government, Prison Service, Frequently Asked Questions <http://www.justice.tas.gov. $\mathrm{au} /$ prisonservice/careers/frequently_asked_questions $>$.

140 Northern Territory Government, Trainee Correctional Officer Information Pack (2019) 4 <https:// justice.nt.gov.au/_data/assets/pdf_file/0006/812949/NTCS-recrutiment-web.pdf>.

141 ACT Inspector of Correctional Services, above n 121. 
The South Australian Information Pack provides some useful detail about the 'on the job' training, as follows:

You will receive training, assistance, direction and guidance from qualified Correctional Officers, Accommodation Managers and functional specialists to gain experience in the safe, secure and humane containment of prisoners. You will learn to use a Case Management model which assists prisoners' care, rehabilitation, work skills, social and education development all of which contribute to 10 by 20 policy, reducing recidivism by $10 \%$ by 2020 .

Your work will include providing assistance to legal, medical, educational, social work, community and volunteer support agencies, which assist prisoners' welfare. You will be given practical experience and training in the preparation of incident reports, how to maintain records and operational procedures. You may also assist in interviewing, assessing and supervising prisoners concerning their development and behaviour. ${ }^{142}$

This appears to have some emphasis on the welfare and wellbeing of imprisoned people in the care of the prison staff, as well as training in maintaining safety and security.

There is also a national qualification to become a prison staff member: Certificate III in Correctional Practice (Custodial). Prison staff often complete this course by part-time training undertaken after commencing their employment. ${ }^{143}$ The Certificate involves five core units and 11 elective units. The core units are designed for staff becoming adult, juvenile or community correctional officers and are quite generic. They include 'contribute to achieving the goals of the organisation', 'communicate effectively' and 'maintain security'. ${ }^{144}$

142 This information is from the 'Trainee Correctional Officer Information and Application Pack' that can be downloaded from this website: Government of South Australia, Department for Correctional Services, Become a Correctional Officer, 4 <https://www.corrections.sa.gov.au/careers/ Working-with-prisoners-and-offenders/roles/applying-to-be-a-correctional-officer>.

143 The website for the qualification does not indicate the amount of time required to undertake the qualification. However, the ACT Corrective Services advice to potential recruits notes that they are expected to complete the Certificate during their 12 month probationary period: ACT Inspector of Correctional Services, above n 121.

144 Australian Government, Qualification Details CSC30115 - Certificate III in Correctional Practice (Release 1) <https://training.gov.au/Training/Details/CSC30115\#>. 
All of the five elective units listed for the 'custodial' specialisation are security focused. They include 'maintain security system', 'control incidents using defensive tactics' and 'conduct searches'. There are general electives available that may be more likely to assist staff to comply with the duty to treat imprisoned people in a human rights-consistent manner. These include 'Protect the safety and welfare of vulnerable offenders', 'Maintain the health, safety and welfare of offenders' and 'Manage conflict through negotiation'. However, there are also more security-focused electives that staff could choose from the general list of electives, such as 'Maintain security during escort', 'Operate specialised security equipment', 'Monitor security from control room' and 'Maintain and use security database'. Thus, it may be possible for people to complete the qualification with little, if any, study of subjects that would promote compliance with this prerequisite.

The predominant focus of both corrective services training and the formal qualification for prison staff is maintaining security. It is not the rehabilitation or welfare of imprisoned people. It is also not how staff are to go about managing the vulnerabilities of the prison population outlined in Chapter 1. Nor does it address how to cater for the specific needs of groups that are over-represented, including Indigenous people (although staff may elect to do individual subjects on this as part of their Certificate).

There are also obvious limits to the content that can be covered in the number of weeks that these training courses last. This is especially so in the jurisdictions that have very short courses, such as Victoria, which only provides four weeks of training before new staff commence 'on the job' training in prisons. As a point of comparison, in Norway and Sweden, which are internationally recognised for having more humane prison systems than Anglophone countries, such training is much longer and more comprehensive. ${ }^{145}$ In Norway, prison staff undertake a two-year university degree, and in Sweden they complete a 20-week training course (this was changed from a university-based course in 2012). ${ }^{146}$

145 For a comparison of Nordic and Anglophone prisons see John Pratt and Anna Eriksson, Contrasts in Punishment - An Explanation of Anglophone Excess and Nordic Exceptionalism (Routledge, 2013). 146 Anders Bruhn, Per Åke Nylander and Berit Johnsen, 'From Prison Guards to... What? Occupational Development of Prison Officers in Sweden and Norway' (2017) 18(1) Journal of Scandinavian Studies in Criminology and Crime Prevention 68, 73-4. 
International human rights law has some particular requirements about the training that prison staff should be provided with, particularly in relation to the prohibition of TCID. Mandela Rule 75(2) requires that staff should be provided with 'training tailored to their general and specific duties, which shall be reflective of contemporary evidence-based best practice in penal sciences', and Rule 76 stipulates that this should include 'at a minimum' the following topics:

(1) (a) Relevant national legislation, regulations and policies, as well as applicable international and regional instruments, the provisions of which must guide the work and interactions of prison staff with inmates;

(b) Rights and duties of prison staff in the exercise of their functions, including respecting the human dignity of all prisoners and the prohibition of certain conduct, in particular torture and other cruel, inhuman or degrading treatment or punishment.

(2) Prison staff who are in charge of working with certain categories of prisoners, or who are assigned other specialized functions, shall receive training that has a corresponding focus.

The Bangkok Rules further provide, '[a]ll staff assigned to work with women prisoners shall receive training relating to the gender-specific needs and human rights of women prisoners'. One specific matter was picked up by the Tasmanian Ombudsman in response to their investigation of strip searching in the Hobart Reception Prison. The Ombudsman recommended that 'training material on strip searching specifically address the impact it can have on the victims of sexual assault.'. ${ }^{147}$

GC 20 further requires that 'persons involved in the custody or treatment of any individual subjected to any form of arrest, detention or imprisonment must receive appropriate instruction and training' on the prohibition against TCID. ${ }^{148}$

147 Ombudsman Tasmania, above n 102, 25, Recommendation 4. This is supported by the international handbook for prison staff on a human rights approach to prison management: Coyle and Fair, above n 71, 48.

148 United Nations Human Rights Committee, above n 12, [10]. 
The Council of Europe's European Code of Ethics for Prison Staff is another useful resource. ${ }^{149}$ It provides nine guidelines for staff conduct that relate specifically to the treatment of imprisoned people with humanity and respect. For example, guideline 13 provides that '[p] rison staff shall respect and protect the physical, sexual and psychological integrity of all prisoners, including against assault by fellow prisoners or any other person', and guideline 15 provides that '[p]rison staff shall only interfere with individual's right to privacy when strictly necessary and only to achieve a legitimate objective'. The Code also provides guidelines about acting with integrity (5-9); providing care and assistance (19-22); and behaving with fairness, impartiality and non-discrimination (23-27). It recommends specific groups have their needs catered for, as follows: '[p] rison staff shall be sensitive to the special needs of individuals, such as juveniles, women, minorities, foreign nationals, elderly and disabled prisoners, and any prisoner who might be vulnerable for other reasons, and make every effort to provide for their needs' (guideline 19).

A training provider would need a lot more guidance than the above to teach staff how these substantive obligations apply on a daily basis at an operational level. There is an Australian example of prison staff training that does encompass human rights. This is the training provided to staff at the AMC. The training covers the legal provisions in the Human Rights Act 2004 (ACT) and Corrections Management Act 2007 (ACT), which, as noted in Chapter 5, represent the most comprehensive human rights protections afforded to imprisoned people in Australia (at least on paper). Between the two Acts, they cover the prohibition of TCID, the requirement that people be treated with humanity and respect, and references to rehabilitation. ${ }^{150}$

Bartels and Boland have noted that:

[n]ew officers also receive training on the detainee life cycle, giving them a deeper understanding of the detainee journey in, through and out of the criminal justice system, and their role in rehabilitation. In addition, new officers receive training on working with women detainees, which supports understanding of their particular vulnerabilities. ${ }^{151}$

149 Recommendation CM/Rec (2012) 5 of the Committee of Ministers to Member States on the European Code of Ethics for Prison Staff (Adopted by the Committee of Ministers on 12 April 2012 at the 1140 th meeting of the Ministers' Deputies).

$150 H R A$ ss 10 (prohibition of TCID), 19 (requirement for treatment with humanity and respect); $C M A$ ss 7 (objects), 9 ('treatment of detainees generally').

151 Lorana Bartels and Jeremy Boland, 'Human Rights and Prison. A Case Study from the Australian Capital Territory' in Leanne Weber et al (eds), The Routledge International Handbook of Criminology and Human Rights (Routledge, 2017) 564. 
Therefore, the ACT provides a model for prison staff training in other jurisdictions, regardless of whether those jurisdictions have statutory protections of the relevant human rights.

\section{Valuing the Work Carried Out by Prison Staff}

If staff feel that their role is valued by the community, they are more likely to treat imprisoned people with respect because they will feel respected themselves. Unfortunately, the literature suggests that prison staff do not currently feel that their work is valued. They feel that the good work they do remains 'invisible' and that their work only receives public attention when there are problems, such as escapes, riots, or suicides. ${ }^{152}$

This was the subject of a report by the NSW Inspector of Custodial Services entitled The Invisibility of Correctional Offcer Work. ${ }^{153}$ The report summarised international and Australian research about the lack of recognition of prison staff as an occupation, with the work generally accorded a low status. ${ }^{154}$ This, combined with the lack of public attention about positive achievements of staff, led the Inspector to conclude that 'there remains a high degree of invisibility associated with the work ... and as a consequence there is an absence of understanding of it or appreciation for the outcomes that work produces, even as it saves lives'. ${ }^{155}$

The report indicates that the work environment of the prison is extremely challenging and stressful, due to factors such as the complex needs of the prison population, propensity for violence and architecture and conditions in the buildings. ${ }^{156}$ It examines the effects of this work environment on staff. ${ }^{157}$ The report recommended that the NSW Parliament 'pass a motion recognising Correctional Officers'. ${ }^{158}$

Subsequently, in January 2017, NSW Corrective Services held the first 'National Corrections Day', which was followed by 'National Corrections Day' in January 2019 and 2020. The aim of this was to pay

152 Alison Liebling, David Price and Guy Shefer, The Prison Officer (Taylor and Francis, $2^{\text {nd }}$ ed, 2010) 155.

153 NSW Inspector of Custodial Services, Report No. 1 - The Invisibility of Correctional Officer Work (2014).

154 Ibid 6-7.

155 Ibid 7.

156 Ibid 8-11, 14, 18-20.

157 This discussion is divided into 'cognitive', 'emotional' and 'behavioural' effects: ibid 26.

$158 \mathrm{Ibid}$ 3. It is unclear whether such a motion was in fact passed. 
'tribute to corrections staff throughout Australia' and draw attention to 'the challenging and often dangerous work they do each day to keep the community safe'. ${ }^{159}$

The report and the national day of recognition represent positive steps towards valuing the work done by prison staff. Another important means by which the value placed on prison work could be increased is to establish it as a desirable, professional career for people - a career that requires professional training and accreditation. ${ }^{160}$ Coyle writes that 'new prison staff need to be properly selected, assessed and trained and throughout their career they need to be given the opportunity to expand and develop their skills. If this does not happen then they are likely to remain one of the most undervalued sectors of public employees. ${ }^{161}$ Achieving this goal would involve increasing the level of qualifications required to become a prison employee beyond the current training requirements outlined in the previous section.

The value placed on prison work could also be increased by emphasising that the role is a social service, aimed at achieving rehabilitation and restoration in accordance with the third prerequisite (discussed in Chapter 6). Staff may be seen as role models for imprisoned people, helping them on their path to becoming law-abiding citizens upon their release. ${ }^{162}$ This is likely to appeal to the community because the community would prefer that imprisoned people are no longer a threat to them upon their release.

It would also be helpful to increase the general public's understanding of the role. If it is emphasised that prison staff prepare people for re-entry into society as law-abiding citizens less likely to commit further crime, the public may be more likely to view the role of prison staff favourably. This could be pursued alongside the education of the public aimed at generating public support to reduce reliance on imprisonment, as recommended in Chapter 4.

159 NSW Government, Communities and Justice, National Corrections Day <https://www. correctiveservices.justice.nsw.gov.au/Pages/CorrectiveServices/national-corrections-day.aspx>.

160 Andrew Coyle, Managing Prisons in a Time of Change (International Centre for Prison Studies, 2001) 83 .

161 Ibid 86.

162 Helen Arnold, 'The Prison Officer' in Yvonne Jewkes et al (eds), Handbook on Prisons (Routledge, 2016) 267-8. This sentiment is reflected in Principle 2.4.2 of the Guiding Principles, which requires that 'Staff model prosocial behaviour by treating all persons with decency, respect and fairness': Corrective Services Administrators' Conference (Cth), Guiding Principles for Corrections in Australia (2018) 14. 
When OPCAT-compliant monitoring commences in Australia, because it will have a preventive focus, it should be highlighting examples of best practice. These examples should include best practice in the treatment of imprisoned people by staff. When the reports of the National Preventive Mechanism (established under the OPCAT) are made publicly available, this will serve multiple purposes. It will simultaneously reduce the invisibility of prison staff work, highlight to the community that this work is extremely valuable when it is done well, and hopefully counter prison staff perception that their work is misunderstood and undervalued, consequently increasing the respect they have for themselves and the imprisoned people in their care.

\section{Conclusion}

The problematic practices in Australian prisons detailed in this chapter clearly constitute human rights violations by prison staff, particularly the prohibition of TCID and duty to treat people with humanity and respect. This was shown by the outline of the international human rights law framework, followed by the discussion of problematic practices across a range of jurisdictions in the four areas of (1) use of solitary confinement, (2) access to medical care, (3) strip searching of women and (4) disrespectful treatment, particularly of Indigenous people.

While much of this chapter focused on the role of staff, it does not follow that any individual staff member in any individual prison can bear the entire burden of rights compliance. Many of the problematic practices stem from departmental policies that prison staff have no choice but to comply with. Other problems stem from inadequate training (due often to its short duration) and inadequate attention given during training to imprisoned people's welfare, managing people with complex needs or the duty to treat imprisoned people consistently with international human rights law obligations. Changes to these systemic problems will better enable individual staff to adopt more human rights-compliant conduct.

Other prerequisites proposed in this book are necessary for addressing this. Reduced reliance on imprisonment in accordance with the first prerequisite will assist because when there are fewer people in prisons there are better conditions for those that remain, and prisons become 
easier for staff to manage. When prisons are crowded it is easier for people to be reduced to numbers, rather than called by their names, and they can become 'bodies' or numbers to be delivered from one place to another. ${ }^{163}$

There also needs to be legislation that prohibits TCID, particularly prolonged solitary confinement, as detailed in Chapter 5. That legislation should also override policies such as the South Australian one requiring imprisoned people seeking medical care be shackled, regardless of whether they pose a danger or escape risk. The legislation should reduce the emphasis on security and good order. While recognising that security always remains a necessary priority for the welfare of imprisoned people and staff, a balance must be struck to accommodate other priorities, including treatment of people with humanity and respect.

These changes need to be overseen by regular OPCAT-compliant inspection that has a preventive focus. As was noted in Chapter 3, the reasons for continual oversight is that:

regular monitoring helps keep the quality of correctional services high, because the staffs knowledge that an inspector could arrive at any time acts as a means of informal control over staff behavior. In other words, it 'keeps staff on their toes' and helps them avoid complacency, even when everything is going well. ${ }^{164}$

These systemic changes should be accompanied by specific strategies to improve staff compliance with their duty suggested in this chapter. These reforms include (1) having the right leaders to drive the necessary reform, (2) comprehensive human rights-based training of prison staff and (3) ensuring the community values the work done by prison staff. Some of these can be pursued on a state/territory-wide basis, particularly improvements to training and improving community perceptions of the work done by prison staff (as exemplified by NSW). Others, such as improved leadership, can be pursued in individual prisons.

163 Coyle, above n 160, 93.

164 Michele Deitch, 'Distinguishing the Various Functions of Effective Prison Oversight' (2010) 30

Pace Law Review 1438, 1443. 
This text is taken from Towards Human Rights Compliance in Australian Prisons, by Anita Mackay, published 2020 by ANU Press, The Australian National University, Canberra, Australia. 